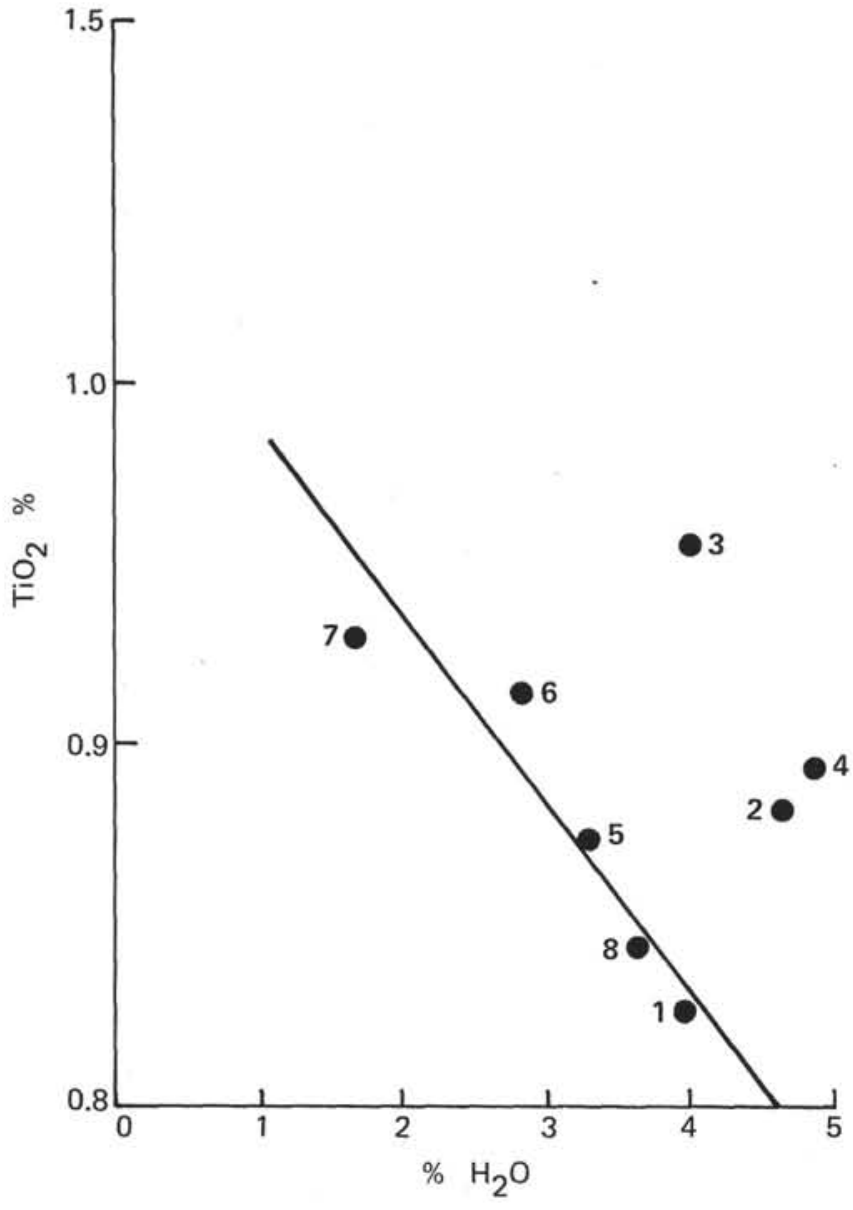

Figure 6. $\mathrm{TiO}_{2}-\mathrm{H}_{2} \mathrm{O}$ plot of Core 7 samples. (Sample numbers same as in Figure 1.)

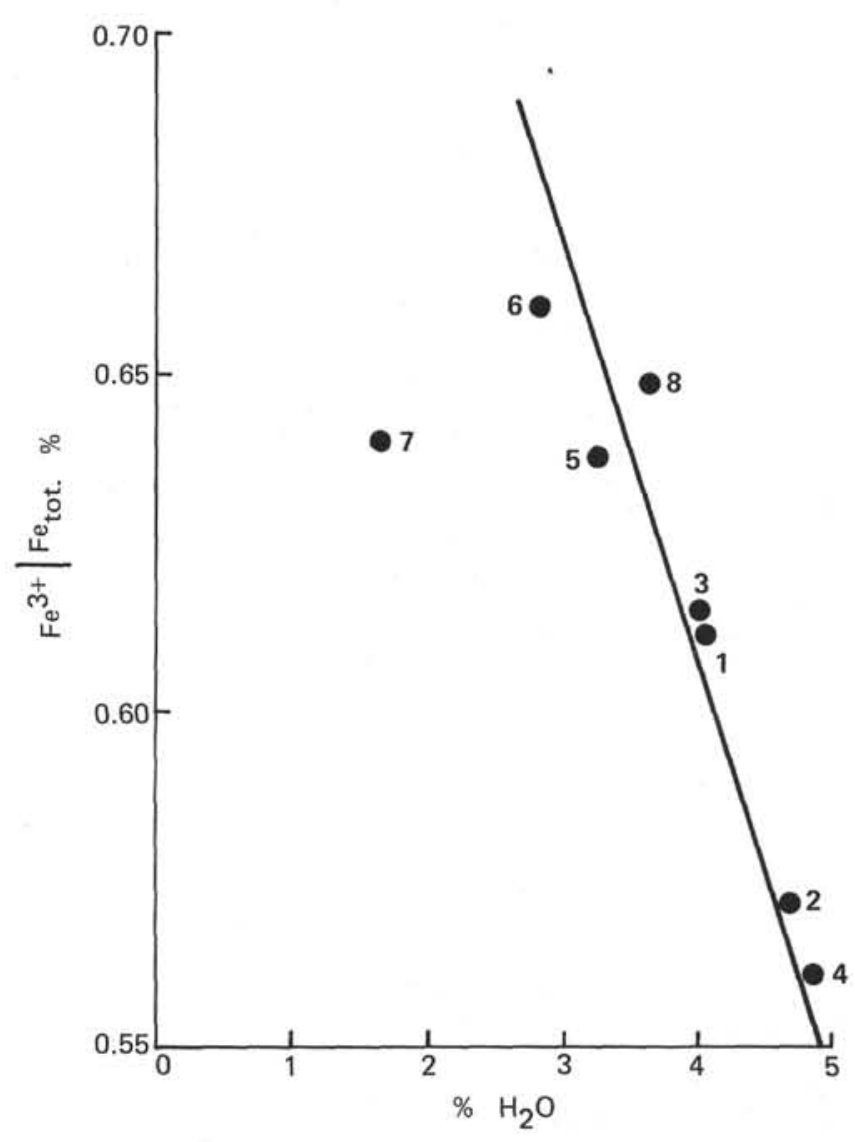

Figure 7. $\mathrm{Fe}^{3+} / \mathrm{Fe}_{\text {total }}$ vs. $\mathrm{H}_{2} \mathrm{O}$. (Sample numbers same as in Figure 1.)

\title{
20.2. K/Ar AGE DETERMINATIONS ON BASALT ROCKS FROM HOLE 373A
}

\author{
C. Savelli and E. Lipparini, Laboratorio di Geologia Marina, CNR, Bologna, Italy
}

Three basalt rock specimens from Hole $373 \mathrm{~A}$ were analyzed. Two are from lithologic Unit IV (Core 7, Section 2). Sample 1 (Table 1) was from the interval $67-76 \mathrm{~cm}$ and Sample 2 from $5-12 \mathrm{~cm}$. The samples were chosen as being the freshest of a total of five samples from Core 7 at our disposal. Two other samples (from cores 12 and 4, respectively) are not analyzed because of obvious alteration. The basalt in the analyzed samples is porphyritic and has phenocrysts of plagioclase, "iddingsitized" olivine, and rare brown spinel in a groundmass consisting of plagioclase, pyroxene, olivine, ore, and alteration products (mainly those of glass, smectites, and limonite). Further, a secondary mineral is calcite, which fills some of the void spaces of the rock. Plagioclase and pyroxene crystals are fresh, as is shown in Figure 1.

The third specimen was from lithologic Unit V (Core 12, section 1, $120 \mathrm{~cm}$; Sample 3 of Table 1). Its petrographic composition corresponds fairly well with the average composition of the whole unit as given above: plagioclase $45 \%$ to $60 \%$, pyroxene $20 \%$ to $25 \%$, and alteration minerals $20 \%$ to $30 \%$. Plagioclase and pyroxene crystals are significantly altered as is shown in Figure 2.

For argon isotopic determinations high-frequency induction heating and an all-metal mass spectrometer were used. Samples were preheated in vacuum at about $160^{\circ} \mathrm{C}$ for $20 \mathrm{hr}$. Potassium was analyzed by 
TABLE 1

K-Ar Age Data on Whole-Rock Samples

\begin{tabular}{|c|c|c|c|c|c|}
\hline & $\begin{array}{l}\text { wt } \% \\
\mathrm{~K}_{2} \mathrm{O}^{2}\end{array}$ & $\begin{array}{l}\text { Quan- } \\
\text { tityb } \\
\text { Fused } \\
\text { (g) }\end{array}$ & $40 \mathrm{Ar}_{\mathrm{rad}} \mathrm{sec} / \mathrm{g}$ & $\% 40 \mathrm{Ar}_{\mathrm{rad}}$ & $\begin{array}{l}\text { Radio- } \\
\text { metric Age } \\
\text { (m.y.) and } \\
\text { Standard } \\
\text { Deviation } \\
(1 \sigma)\end{array}$ \\
\hline $\begin{array}{l}\text { Sample, } 1 \text { (f.169) } \\
\text { Core } 7\end{array}$ & 0.20 & 2.737 & $0.048 \times 10^{-6}$ & 10.5 & $7.2 \pm 0.8$ \\
\hline $\begin{array}{l}\text { Sample, } 1 \text { (f.176) } \\
\text { Core } 7\end{array}$ & 0.20 & $2.46_{6}$ & $0.046 \times 10^{-6}$ & 8.6 & $6.9 \pm 0.8$ \\
\hline $\begin{array}{l}\text { Sample 2, (f.177) } \\
\text { Core } 7\end{array}$ & 0.23 & $2.68_{3}$ & $0.057 \times 10^{-6}$ & 10.5 & $7.4 \pm 0.8$ \\
\hline Sample 3, (f.191) & 0.32 & $4.73_{1}$ & $0.046 \times 10^{-6}$ & 6.9 & $4.4 \pm ?$ \\
\hline
\end{tabular}

Note: Analysts: E. Lippanini and C. Savelli Decay constants used: $\lambda_{e}=0.585 \times 10^{-10} \mathrm{yr}^{-1}, \lambda_{\beta}=4.72 \times 10^{-10} \mathrm{yr}^{-1}$ and $40 \mathrm{~K} / \mathrm{K}_{\text {tot }}=0.0122 \mathrm{wt} \%$.

a Average of 2 determinations.

b The $-1+0.25 \mathrm{~mm}$ fraction of the rock was used after crushing and washing with distilled water.

means of atomic absorption in solutions containing cesium. Details of analytical techniques are reported in Savelli, 1973.

Table 1 shows the analytical K-Ar data. Radiometric ages of Samples 1 and 2 range from 6.9 to 7.4 m.y. and have an average value of $7.2 \pm 0.8$ m.y. The high \pm value results from the low radiogenic argon (low $\mathrm{K}$ ) contents of the rocks. According to a radiometric scale of the Neogene by Selli (1970), the chronostratigraphic position of this basalt corresponds to the Messinian stage.

The K-Ar age of Sample 3 is 4.4 m.y.. The sample was taken from about 84 meters below Samples 1 and 2. Nevertheless, it has a radiometric age younger than that of the samples above. Because of their freshness (Figures 1 and 2), Samples 1 and 2 are expected to have radiogenic argon retentions and therefore radiometric ages greater than those of Sample 3. The K-Ar data of Table 1 confirm this fact. Thus, the age of Sample 3 (4.4 m.y.) can be regarded as a minimum age.

During the time span between the ages reported here (7.4-4.4 m.y.) significant volcanic activity occurred in both land and marine areas surrounding the area of the central Tyrrhenian Sea (Selli, 1974). This regional activity has petrochemical characteristics differing from those of the drill site basalts. K-Ar data available for the volcanics from the above-mentioned areas are summarized as follows:

Capraia Island: $9.5-4.8$ m.y. ${ }^{1}$

S. Vincenzö: 4.7 m.y. ${ }^{2}$

Tolfa-Cerite area: 6.4-2.1 m.y. ${ }^{2}$

Cava Simoni (Rome): 4.3 m.y.

Pontine Islands: 5-1.2 m.y.

Ischia Island: 6-0.8 m.y. Iblei Mt. (SE Sicily) 5.4-

1.7 m.y. (Barberi et al., 1974)

Capo Ferrato (SE Sardinia): 5 m.y. (this lab; data to be published).

\section{ACKNOWLEDGMENTS}

Thanks are due to R. Selli, M. Del Monte, J. Hunziker, D. Vass, and G. Beccaluva who critically reviewed the manuscript.

\section{REFERENCES}

Barberi, F., Civetta, L., Gasparini, P., Innocenti, F., Scandone, R., and Villari L., 1974. Evolution of a section of the Arica-Europe plate boundary: paleomagnetic and volcanological evidence from Sicily: Earth Planet. Sci. Lett., v. 22, p. 123-132.

Gasparini, P. and Adams, J.A.S., 1969. K-Ar dating of Italian Plio-Pleistocene volcanic rocks: Earth Planet. Sci. Lett., v. 6 , p. $225-230$.

Lombardi, G., Nicoleti, M., and Petrucciani, C., 1974. Eta delle vulcaniti acide dei complessi Tolfetano, Cerite e Manziate (Lazio nord-occidentale): Periodico Mineralogia, v. 43 , p. $351-375$.

Savelli C., 1973. Linea per misure di argon 40 radiogenico del Laboratoria di Geologia Marina (CNR): Gior. Geol., v. 39 , p. 61 .

Selli R., 1970. Report on the absolute age. Comm. Medit. Neogene Stratig., Proc. IV Sess., Bologna, 1967: Giorn. Geol., v. 35, p. 51 .

1974. Appunti sulla geologia del Mar Tirreno: Rendiconti Semin. Fac. Sci. Univ. Cagliari, v. 43 (suppl.), p. 327

\footnotetext{
${ }^{1}$ Data reported in the papers of Gasparini and Adams (1969) and Lombardi et al. (1974).

${ }^{2}$ Locality: Central Italy (Tyrrhenian side).
} 


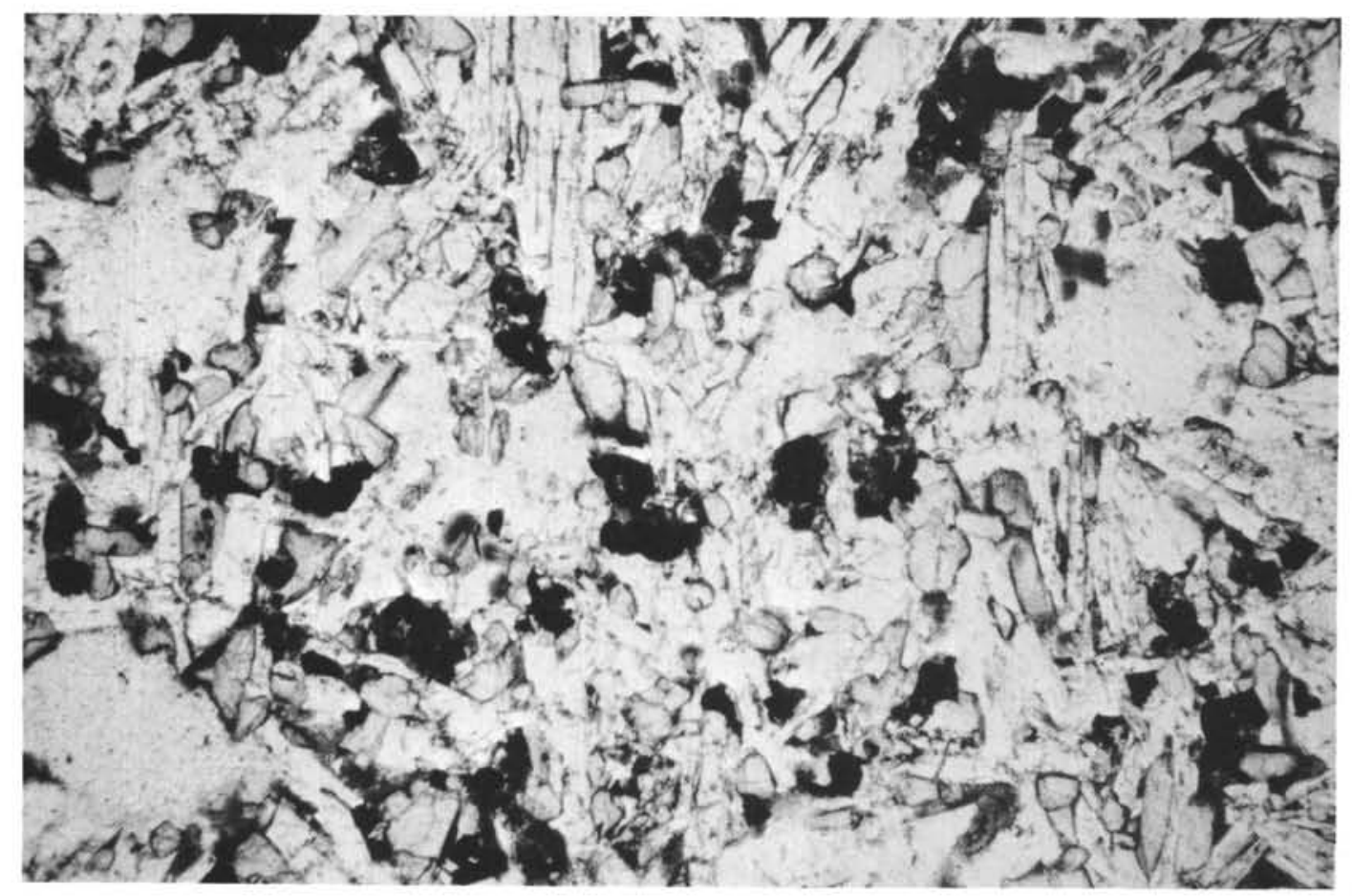

Figure 1. Petrographic microscope photo, polarized light, nicols, 100x, Sample 2. Plagioclase and pyroxene crystals show no alteration products.

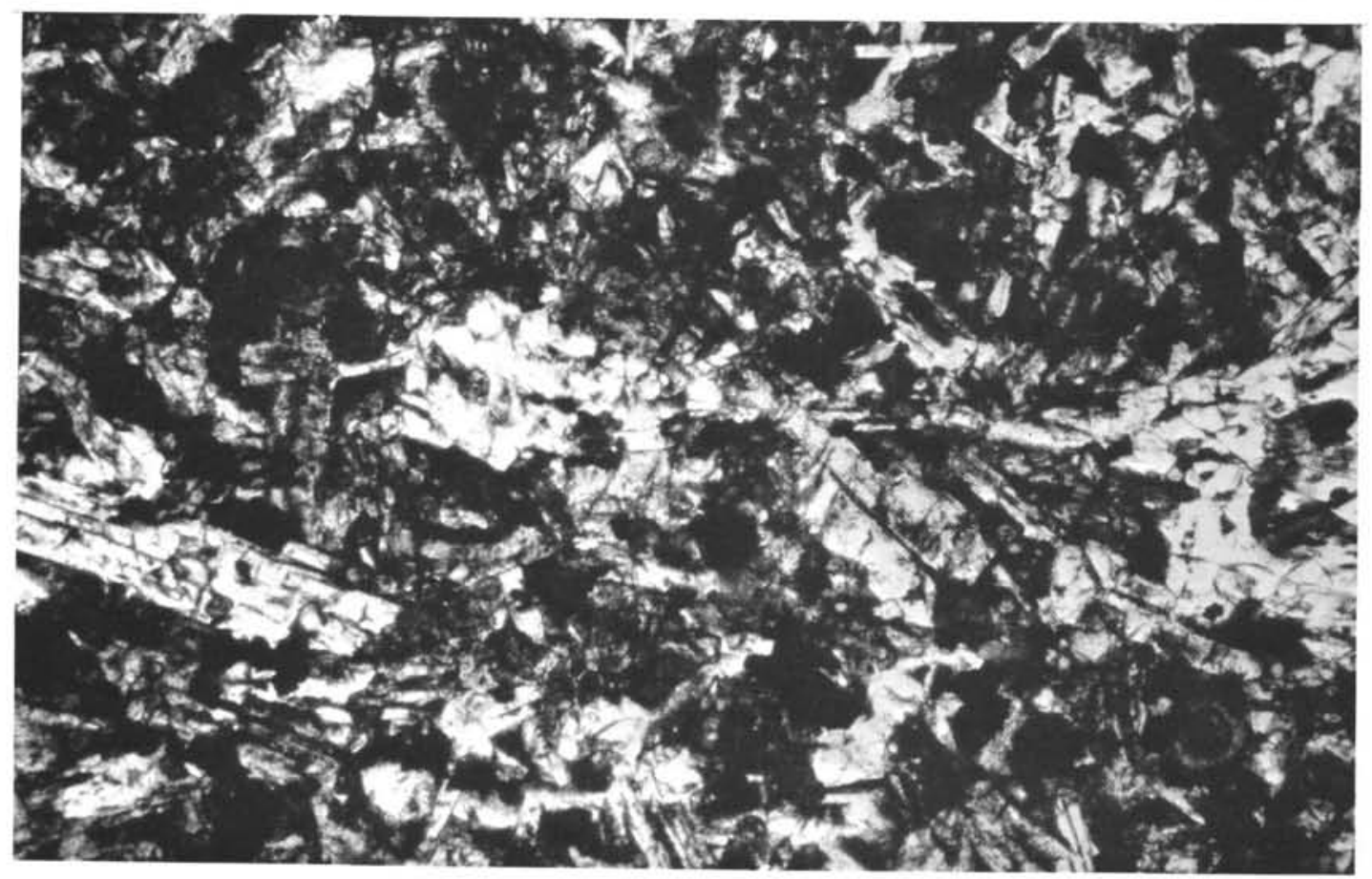

Figure 2. Petrographic microscope photo, polarized light, nicols, 100x, Sample 3. Alteration products of plagioclase and pyroxene crystals are present. 